\title{
Mediastinal Germ Cell Tumor N3 TNM
}

Finding

National Cancer Institute

\section{Source}

National Cancer Institute. Mediastinal Germ Cell Tumor N3 TNM Finding. NCI Thesaurus. Code C146846.

Mediastinal germ cell tumor with metastasis in scalene and/or supraclavicular lymph nodes. (WHO Classification of Tumors of the Lung, Pleura, Thymus and Heart, 2015) 